DOE/RL-96-85

Rev. 0

\title{
Engineering Evaluation Cost Analysis for the 100-B/C Area Ancillary Facilities at the 108-F Building
}




\section{DISCLAIMER}

This report was prepared as an account of work sponsored by an agency of the United States Government. Neither the United States Government nor any agency thereof, nor any of their employees, makes any warranty, express or implied, or assumes any legal liability or responsibility for the accuracy, completeness, or usefulness of any information, apparatus, product, or process disclosed, or represents that its use would not infringe privately owned rights. Reference herein to any specific commercial product, process, or service by trade name, trademark, manufacturer, or otherwise does not necessarily constitute or imply its endorsement, recommendation, or favoring by the United States Government or any agency thereof. The views and opinions of authors expressed herein do not necessarily state or reflect those of the United States Government or any agency thereof. 


\section{DISCLAIMER}

Portions of this document may be illegible electronic image products. Images are produced from the best available original document. 
DOE/RL-96-85

Rev. 0

\section{CONTENTS}

2.0 SITE CHARACTERIZATION . . . . . . . . . . . . . . . . . . . 2-1

2.1 BACKGROUND AND SITE DESCRIPTION $\ldots \ldots \ldots \ldots \ldots \ldots \ldots \ldots . . \ldots . \ldots \ldots$

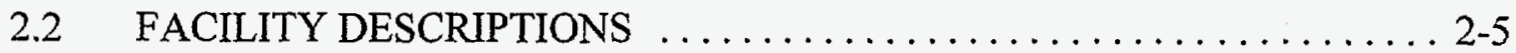

2.2.1 111-B Decontamination Station .................. 2-6

2.2.2 115-B Gas Line Pressure/Vacuum Seal House $\ldots . . . \ldots . . . . .2$. . . . . . . . .

2.2 .3 118-C-4 (105-C) Horizontal Control Rod Cave . . . . . . . . . . . . 2-9

2.2.4 119-B Exhaust Air Sampler Building . . . . . . . . . . . . . . 2-9

$2.2 .5105-C$ Reactor (Waste Disposition Only) . . . . . . . . . . . . 2-9

$2.2 .6 \quad 108-F$ Biology Laboratory . . . . . . . . . . . . . . . . . 2-11

2.3 SOURCE, NATURE, AND EXTENT OF CONTAMINATION . . . . . . 2 2-12

2.4 SITE CONDITIONS THAT JUSTIFY A REMOVAL ACTION . . . . . . . 2-12

3.0 REMOVAL ACTION OBJECTIVES $\ldots \ldots \ldots \ldots \ldots \ldots \ldots \ldots \ldots \ldots \ldots \ldots \ldots$

4.0 IDENTIFICATION OF REMOVAL ACTION ALTERNATIVES . . . . . . . . . . 4-1

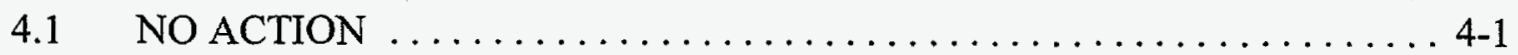

4.2 CONTINUED SURVEILLANCE AND MAINTENANCE . . . . . . . . 4-1

4.3 DECONTAMINATION, DECOMMISSIONING, AND DISPOSAL AT THE

ENVIRONMENTAL RESTORATION DISPOSAL FACILITY . . . . . . . . 4-2

4.4 DECONTAMNATION AND DEMOLITION (OTHER HANFORD FACILITY DISPOSAL) $\ldots \ldots \ldots \ldots \ldots \ldots \ldots \ldots .4 .4$

5.0 COMPARATIVE ANALYSIS OF ALTERNATIVES $\ldots \ldots \ldots \ldots \ldots \ldots \ldots \ldots \ldots .1$

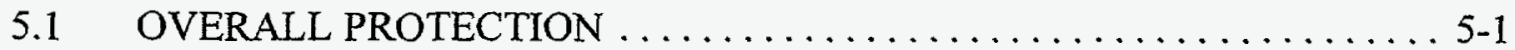

5.2 COMPLIANCE WITH APPLICABLE OR RELEVANT AND

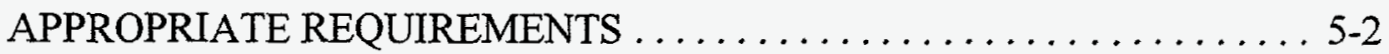

5.2 .1 Chemical -Specific ARARs . . . . . . . . . . . . . . . . 5-2

5.2 .2 Action-Specific ARARs . . . . . . . . . . . . . . . . 5-2

5.2 .3 Location-Specific ARARs . . . . . . . . . . . . . . . . 5-3

5.2.4 Other Criteria, Advisories, or Guidance to be Considered . . . . . . 5-3

5.2 .5 Columbia River Protection Standards . . . . . . . . . . . . . . . 5-4

5.2.6 Cultural and Ecological Resource Protection Standards ..... . . . . . 5-4

5.2 .7 Waste Management Standards . . . . . . . . . . . . . . . . . 5-5

5.2 .8 Air Emission Standards $\ldots \ldots \ldots \ldots \ldots \ldots \ldots \ldots \ldots \ldots \ldots . \ldots \ldots$. 5.5

5.2 .9 Radiation Protection Standards $\ldots \ldots \ldots \ldots \ldots \ldots \ldots \ldots \ldots . \ldots \ldots$

5.2 .10 Polychlorinated Biphenyls . . . . . . . . . . . . . . . 5-6

5.2 .11 Asbestos . . . . . . . . . . . . . . . . . . . . . 5-6

5.2 .12 Worker Protection $\ldots \ldots \ldots \ldots \ldots \ldots \ldots \ldots \ldots . . \ldots \ldots$. . . . . . . . . . . . .

5.3 LONG-TERM EFFECTIVENESS $\ldots \ldots \ldots \ldots \ldots \ldots \ldots \ldots \ldots \ldots \ldots .7$

5.4 REDUCTION OF TOXICITY, MOBILITY, OR VOLUME . . . . . . . . 5-7 
5.5 SHORT-TERM EFFECTIVENESS $\ldots \ldots \ldots \ldots \ldots \ldots \ldots \ldots \ldots \ldots \ldots .6$

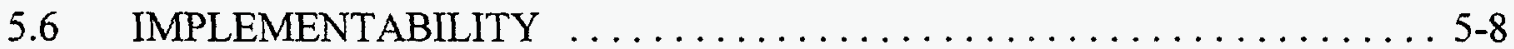

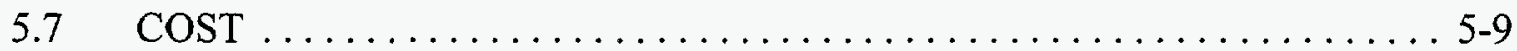

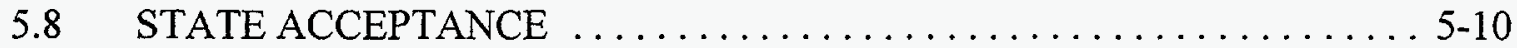



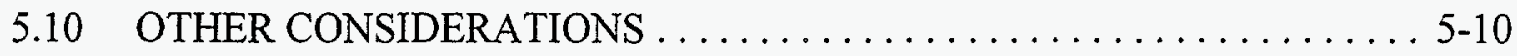

6.0 RECOMMENDED REMOVAL ACTION ALTERNATIVE $\ldots \ldots \ldots \ldots \ldots \ldots .6-1$

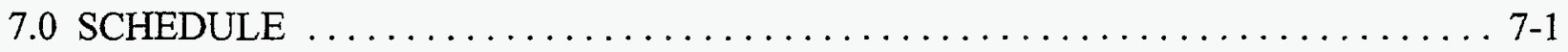

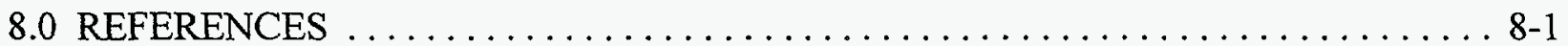

\section{FIGURES}

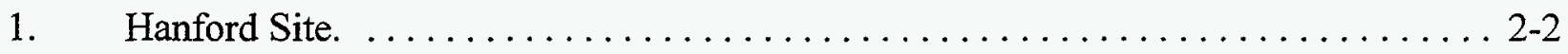

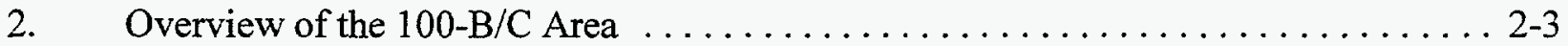

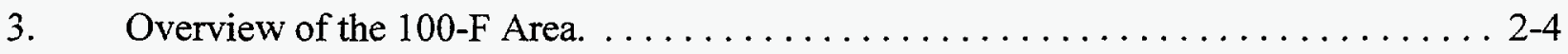

4. Schematic of the 111-B Decontamination Facility. ................ 2-8

5. Schedule for the $100-\mathrm{B} / \mathrm{C}$ Area Ancillary Facilities. . . . . . . . . . . . . $7-2$

\section{TABLES}

1. Waste Generated During 105-C Reactor Safe-Storage Activities ............ 2-11

2. Nature and Extent of Potential Hazardous Substance Contamination in the 100-B/C Area Facilities and the 108-F Biology Laboratory . . . . . . . . . . . 2-13

3. Cost Estimates: Continued Surveillance and Maintenance. . . . . . . . . . . 4-2

4. Environmental Restoration Disposal Facility. .................... 4-5

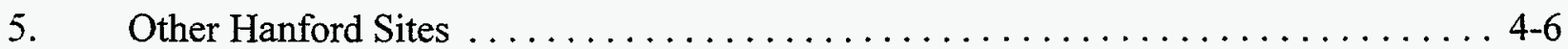

6. Cost Comparison of Decontamination and Demolition and the Continued Surveillance and Maintenance Costs ................ 5-9 


\section{ACRONYMS}

\begin{tabular}{ll} 
ACM & asbestos-containing material \\
ALARA & as low as reasonably achievable \\
ARAR & applicable or relevant and appropriate requirements \\
CERCLA & Comprehensive Environmental Response, Compensation, and Liability Act of \\
& 1980 \\
CFR & Code of Federal Regulations \\
cpm & counts per minute \\
DOE & U.S. Department of Energy \\
dpm & disintegrations per minute \\
Ecology & Washington State Department of Ecology \\
EE/CA & engineering evaluation/cost analysis \\
ERDF & Environmental Restoration Disposal Facility \\
EPA & U.S. Environmental Protection Agency \\
FR & Federal Register \\
LLBG & low-level burial grounds \\
LLW & low-level waste \\
MTCA & Model Toxics Control Act \\
NEPA & National Environmental Policy Act of 1969 \\
PCB & polychlorinated biphenols \\
RCRA & Resource Conservation and Recovery Act of 1976 \\
RL & U.S. Department of Energy, Richland Operations Office \\
ROD & Record of Decision \\
TSCA & Toxic Substances Control Act \\
S\&M & surveillance and maintenance \\
WAC & Washington Administrative Code \\
\hline
\end{tabular}


DOE/RL-96-85

Rev. 0 
DOE/RL-96-85

Rev. 0

\subsection{INTRODUCTION}

The 100 Area of the Hanford Site, along with the 200,300, and 1100 Areas, was placed on the U.S. Environmental Protection Agency's (EPA) National Priorities List in November 1989, under the Comprehensive Environmental Response, Compensation, and Liability Act of 1980 (CERCLA). In 1995, the U.S. Department of Energy (DOE), Richland Operations Office (RL) conducted a removal site evaluation (BHI 1996) of selected facilities in the 100 Area of the Hanford Site in accordance with CERCLA and 40 Code of Federal Regulations (CFR) 300.410. The scope of the evaluation included the aboveground portions of the 108-F Biology Laboratory in the 100-F Area and all inactive ancillary buildings and structures in the $100-\mathrm{B} / \mathrm{C}$ Area, excluding the reactor building and the river outfall. Based on the evaluation, $\mathrm{RL}$ determined that hazardous substances ${ }^{1}$ in the 108-F Biology Laboratory and five of the $100-\mathrm{B} / \mathrm{C}$ Area facilities may present a potential threat to human health or the environment, and that a non-time critical removal action ${ }^{2}$ at these facilities is warranted. This determination was documented in an engineering evaluation/cost analysis (EE/CA) approval memorandum (Appendix $\mathrm{A}$ of $\mathrm{BHI}$ 1996). The EE/CA approval memorandum is the basis on which to proceed with the performance of an $\mathrm{EE} / \mathrm{CA}$ to determine the appropriate removal action.

This report presents the results of the EE/CA for removal alternatives for final disposition of these six facilities. The EE/CA was conducted pursuant to the requirements of CERCLA and 40 CFR 300.415 and is intended to aid RL and the EPA in selecting a preferred removal action.

\footnotetext{
1"Hazardous substances" as used in this document means those substances defined by section 101(14) of CERCLA.

$2^{2}$ "Remove" or "removal", as defined by Section 101(23) of CERCLA, refers to the cleanup or removal of released hazardous substances from the environment; actions if a threat of release of hazardous substances occur; actions to monitor, assess, and evaluate the release (or threat of release) of hazardous substances; the disposal of removed material; or other actions that may be necessary to prevent, minimize, or mitigate damage to public health or welfare or to the environment, which may otherwise result from a release or threat of release. If a planning period of at least 6 months exists before onsite actions must be initiated, the removal action is considered non-time critical and an EE/CA is conducted.
} 
DOE/RL-96-85

Rev. 0 
DOE/RL-96-85

Rev. 0

\subsection{SITE CHARACTERIZATION}

\subsection{BACKGROUND AND SITE DESCRIPTION}

The Hanford Site is located in southeastern Washington State (Figure 1). The 100 Area of the Hanford Site is located along the southern shore of the Columbia River and includes nine inactive plutonium production reactors and related support facilities grouped within six noncontiguous reactor areas. The support facilities were designed to supply, treat, store, and carry away the reactor cooling water and to house utilities, maintenance, and miscellaneous services. On November 3, 1989, the EPA placed the 100 Area on the National Priorities List because of soil and groundwater contamination resulting from the past operation of the reactors and support facilities.

The 100 Areas include many liquid and solid waste disposal sites used to support past reactor operations. To organize cleanup efforts under CERCLA, these sites were subdivided into operable units consisting of waste sites that were related both geographically and by waste site type. The 100-B/C Area contains three operable units: two that consist of the liquid and solid waste disposal sites in the 100-B/C Area (100-BC-1 and 100-BC-2 Operable Units), and one that consists of contaminated groundwater underlying the 100-B/C Area (100-BC-5 Operable Unit). The 100-F Area also contains three operable units: two that consist of liquid and solid waste disposal sites in the 100-F Area (100-FR-1 and 100-FR-2 Operable Units), and one that consists of contaminated groundwater underlying the 100-F Area (100-FR-3 Operable Unit).

Five of the facilities addressed by this EE/CA are located in the 100-B/C Area (site of the $\mathrm{B}$ and $\mathrm{C}$ Reactors; Figure 2). The 100-B/C Area covers 1,834 hectares (742 acres) and is the furthest upstream of the reactor areas. The B Reactor, constructed in 1943, operated from 1944 through 1968, when it was retired from service. The C Reactor, constructed in 1951, operated from 1952 to 1969 , when it was also retired from service. The $C$ Reactor shared some of the support facilities constructed for the B Reactor. Most of the remaining 100-B/C Area facilities have been deactivated and are awaiting final decommissioning. Active facilities, such as the pump station for the Hanford Site water supply system (181-B and 182-B), were not within the scope of the removal site evaluation and are not addressed in this EE/CA.

One of the facilities addressed by this EE/CA is located in the 100-F Area (site of the F Reactor; Figure 3). The 100-F Area covers 256 hectares (632 acres) and is the furthest downstream of the reactor areas. Construction of F Reactor began in December 1943 and it was operated from 1944 through 1965, when it was retired. The 100-F Area originally included several major support facilities, including structures associated with the treatment and storage of reactor cooling water and support buildings for biological experimentation. Most of the 100-F facilities were deactivated with the reactor (beginning in 1965) and have since been demolished. Of the dozen or so reactor-related structures, only the 105-F Reactor Building and the 108-F Biology Laboratory remain standing. 
Figure 1. Hanford Site.

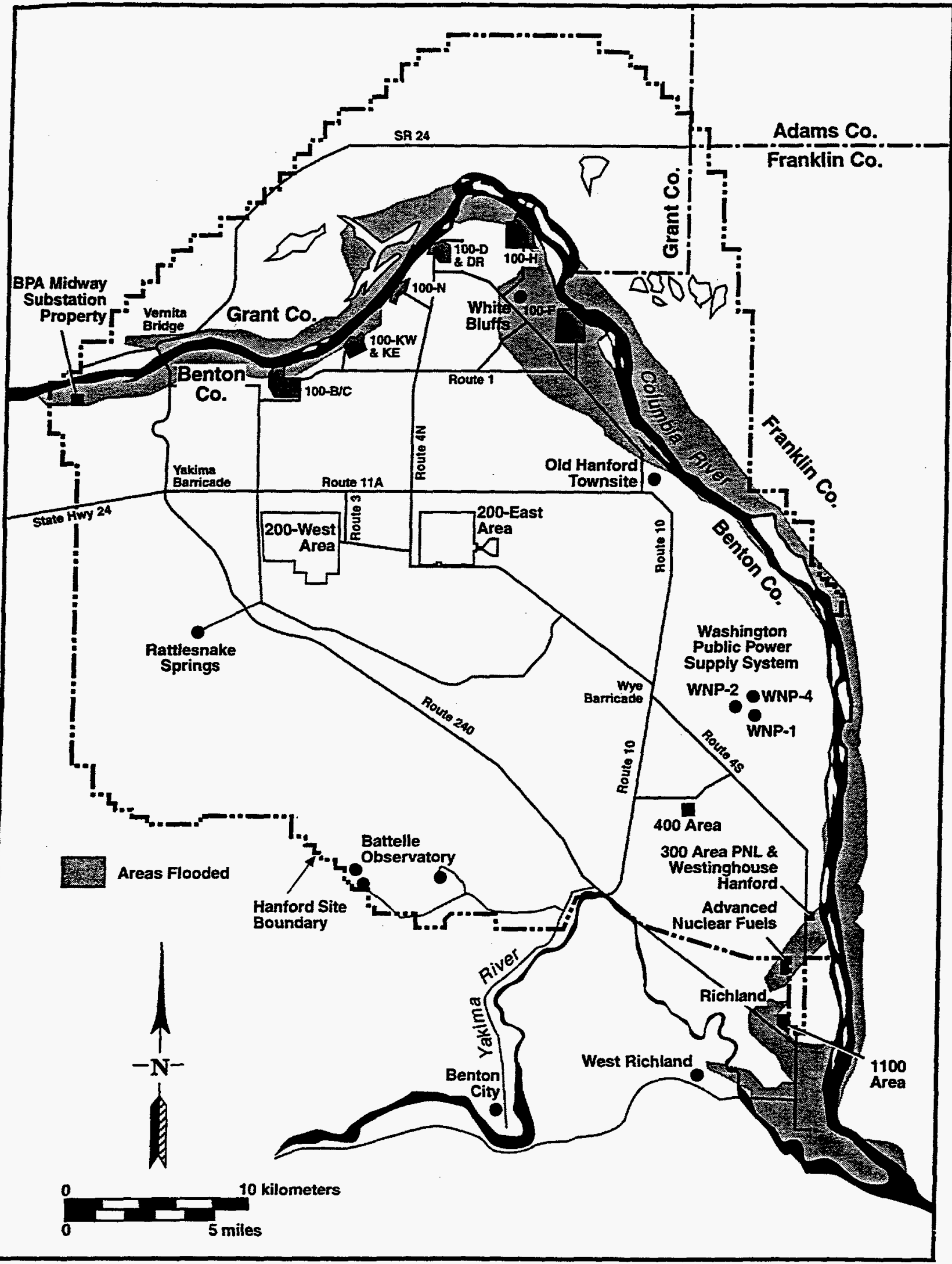


DOE/RL-96-85

Rev. 0

Figure 2. Overview of the 100-B/C Area.











\section{DOE/RL-96-85 \\ Rev. 0}

The decision to proceed with remediation of waste sites in the $100-\mathrm{B} / \mathrm{C}$ Area has been accomplished by issuing the CERCLA Record of Decision (ROD) for many of the liquid waste disposal sites in the 100-BC-1, 100-DR-1, and 100-HR-1 Operable Units. Removal actions conducted under this EE/CA will be coordinated with the waste site remedial actions, as necessary, to ensure consistency of cleanup goals and cost-effective scheduling of field activities.

Public access to the Hanford Site, including the 100 Area, is currently restricted. Current land use in the 100 Area consists of RL-funded fuel management activities and cleanup activities. The Columbia River, which is adjacent to the 100 Area, is accessible to the public and is used for recreational purposes such as boating and sport fishing. In prehistoric and early historic times, the area along the banks of the Columbia River, including the 100 Areas, was a focal point for camping and village sites for Northwestern Indian tribes. More recently, before the U.S. government acquired the land in January 1943, the area was used for irrigated and dry-land farming and livestock grazing, as well as providing camping and village sites for some Northwestern Indian tribes.

The entire area along the Columbia River is rich in cultural resources, including prehistoric and historic sites, Native American artifacts, and sites of religious significance (Cushing 1995). Three archeological sites lie partially within the 100-B/C Area and others are located near the area. The 105-B Reactor Building is listed on the National Register of Historic Places and is designated as a National Historic Mechanical Engineering Landmark and National Civil Engineering Landmark. Other buildings in the 100-B/C Area are being evaluated for eligibility. Eight archeological sites have been identified within the 100-F Area and an additional six within $2 \mathrm{~km}(1.2 \mathrm{mi})$ of the area. The principal historic site near the 100-F Area is the East White Bluffs ferry landing and former townsite, which has been considered for nomination to the National Register of Historic Places, although no formal documentation has been prepared.

The plant community within the perimeter of each 100 Area is characterized primarily as cheatgrass/rabbitbrush, with a riparian community in a narrow strip along the Columbia River shoreline. Many areas within the reactor areas have been physically disturbed by construction and operation of the reactors, support facilities, and waste sites. The habitats along the Columbia River are used by a variety of mammals, birds, reptiles, and insects. Three species of birds on the federal list of threatened or endangered species reside at the Hanford Site (Cushing 1995). One of the threatened species is the bald eagle, which has roost locations near the 100-F Area. Further information on ecological resources in the 100 Areas and threatened, endangered, and candidate species is available in Cushing (1995).

\subsection{FACILITY DESCRIPTIONS}

The 100 Area facilities addressed in this EE/CA have been deactivated to place them in a safe and stable condition that minimizes the long-term cost of surveillance and maintenance (S\&M) and is protective of workers, the public, and the environment. Deactivation includes disassembly and removal of radiologic and hazardous substances, as appropriate; removal of all easily removable tools and equipment; and decontamination or fixing (application of a fixative) of 
remaining structures, systems, and components as necessary to prevent the spread of contamination during long-term storage. These deactivation activities prepare the facility to lie idle with minimal maintenance, and protect $S \& M$ workers as they enter for quarterly or annual surveillance.

With the exception of the 105-C Reactor facility, the facilities addressed in this EE/CA have not been fully characterized, although most have been subject to past radiation surveys. Information regarding hazardous substances in these facilities is based primarily on knowledge of construction materials, historical operations, process knowledge, and characterization of associated facilities in the 100 Areas. A description of each facility is provided in the following sections. Information on the nature and extent of contamination is provided in Section 2.3. Primary references for the facility information are Atomic Energy Commission-General Electric Corp (AEC-GE) Study Group for the Economic Development of Richland (1964); Dorian and Richards (1978); Douglas United Nuclear (1971); Gerber (1993a, 1993b); Kiser (1984); Kiser and Witt (1994); and Wahlen (1991).

The research for this EE/CA has lead to the discovery of incorrect facility name and number. The correct number and name are presented here, with reference to the "common" name and number to avoid confusion with other 100 Area documents.

\subsubsection{1-B Decontamination Station}

The 111-B Decontamination Station has also been known as the 111-B Fuel Examination Facility or Radiometallurgy Laboratory. The 111-B Decontamination Station was constructed in 1951 and operated as the first fuel failure inspection facility until 1968. Irradiated fuel sources were stored and examined in steel tanks filled with water. Waste from the steel examination tanks was held in subsurface concrete storage tanks. The two subsurface concrete waste storage tanks, 1.7 $\mathrm{m}$ wide by $3.2 \mathrm{~m}$ long by $2.8 \mathrm{~m}$ deep ( $5.75 \mathrm{ft}$ wide by $10.67 \mathrm{ft}$ long by $9 \mathrm{ft}$ deep) are adjacent to each other as shown in Figure 4. The majority of the building was aboveground, but part of the building housing the concrete waste storage tanks was approximately $4.5 \mathrm{~m}(15 \mathrm{ft})$ belowground. The tanks were filled with concrete several years ago to stabilize internal contamination. Later, the 111-B facility was used as a decontamination station and storage facility for various items of reactor hardware such as irradiated reactor components.

The aboveground structure was demolished in 1983, but the concrete floor slab and subsurface tanks were left in place. The truck ramp to the tanks was filled with soil, and a concrete pad was poured over the entire structure. In 1986, a routine survey report recorded 30,000 counts per minute $(\mathrm{cpm}) 0.6 \mathrm{~cm}(0.25 \mathrm{in})$. from hot spots on the concrete pad. The pad was fixed with an asphalt sealant and marked with a radioactive contamination marker (metal plate).

The 116-B-6A Crib is located on the inside corner of the original " $L$ "-shaped structure and contains soil contaminated with liquid effluents from the 111-B Building. On the opposite side of the slab is a small solid waste burial ground (116-B-6B), for unknown system wastes from the 105-B Reactor Building. Solid wastes from the 111-B Building may also be resident in this burial site. Neither the crib nor the burial ground are included within the scope of this $\mathrm{EE} / \mathrm{CA}$ 
and will be managed under the remedial action program. Past crib sampling efforts may indicate the type of hazardous substances remaining in the facility. Radioactive crib contaminants included ${ }^{90} \mathrm{Sr},{ }^{137} \mathrm{Cs}$, ${ }^{60} \mathrm{Co},{ }^{155} \mathrm{Eu}$, and ${ }^{239} \mathrm{Pu}$. Nonradioactive hazardous substances included sodium dichromate, sodium oxalate, and sodium sulfamate (Dorian and Richards 1978).

In addition to these contaminants within the crib, it is assumed (based on process knowledge) that pieces of irradiated reactor fuel may remain within the waste storage tanks.

\subsubsection{5-B Gas Line Pressure/Vacuum Seal House}

The 115-B Gas Line Pressure/Vacuum Seal House has also been incorrectly identified in other documents as the 1608-B Gas Line Pressure/Vacuum Seal House. The 115-B Gas Line Pressure/Vacuum Seal House consists of three components:

- A small, wooden-frame structure at grade (approximately $2.3 \mathrm{~m}^{2}\left[24 \mathrm{ft}^{2}\right]$ ) with a wooden roof and composition surface, used to provide shelter for monitoring instruments

- A concrete structure primarily belowgrade (less than $1 \mathrm{~m}[3 \mathrm{ft}]$ of the concrete structure projects above the soil surface) with dimensions $9.8-\mathrm{m}$ high, $3.7-\mathrm{m}$ long, and $3-\mathrm{m}$ wide (30-ft high, 21-ft long, and 9-ft wide)



The facility was built in 1960 as an auxiliary building to the 115-B/C Gas Recirculation Facility. The subsurface of this auxiliary structure is connected to the 105-B Reactor Building by concrete ducts (approximately 6-m [20-ft] long), which house piping through which flowed the recirculating reactor block inert cover gas. The cover gas was monitored by the equipment within the aboveground portion of the 115-B Gas Line Pressure/Vacuum Seal House. Piping in the subsurface ducts conducted reactor cover gas to the 115-B/C Gas Recirculation Facility, which was demolished in 1989 (Griffin 1989). Approximately $15 \mathrm{~m}(50 \mathrm{ft})$ of the ducts and piping remain beyond the 115-B Gas Line Pressure/Vacuum Seal House (between the facility and a burial ground which overlies the ducts).

Two tanks were contained in seal pits in the concrete subsurface structure. They were removed as part of deactivation and transported to low-level burial grounds (LLBG) in the 200 West Area. The seal pit oil was packaged, solidified, and also transported to the burial grounds for disposal.

Records of radiologic surveys of this facility do not exist. However, surveys performed of the ducting nearest the 115-B Gas Line Pressure/Vacuum Seal House (in preparation for demolition of the main 115-B Building in 1989) are presented in Table 2. Both these surveys and sampling of B Reactor gas ducting, which runs through the 115-B Gas Line Pressure/Vacuum Seal House, indicate the presence of radioactive contaminants (Griffin 1989). In addition, a mercury thermostat and manometer remain in the aboveground wooden-frame structure.

The walls and roof of the exterior structure are in poor condition. 
DOE/RL-96-85

Rev. 0

Figure 4. Schematic of the 111-B Decontamination Facility.

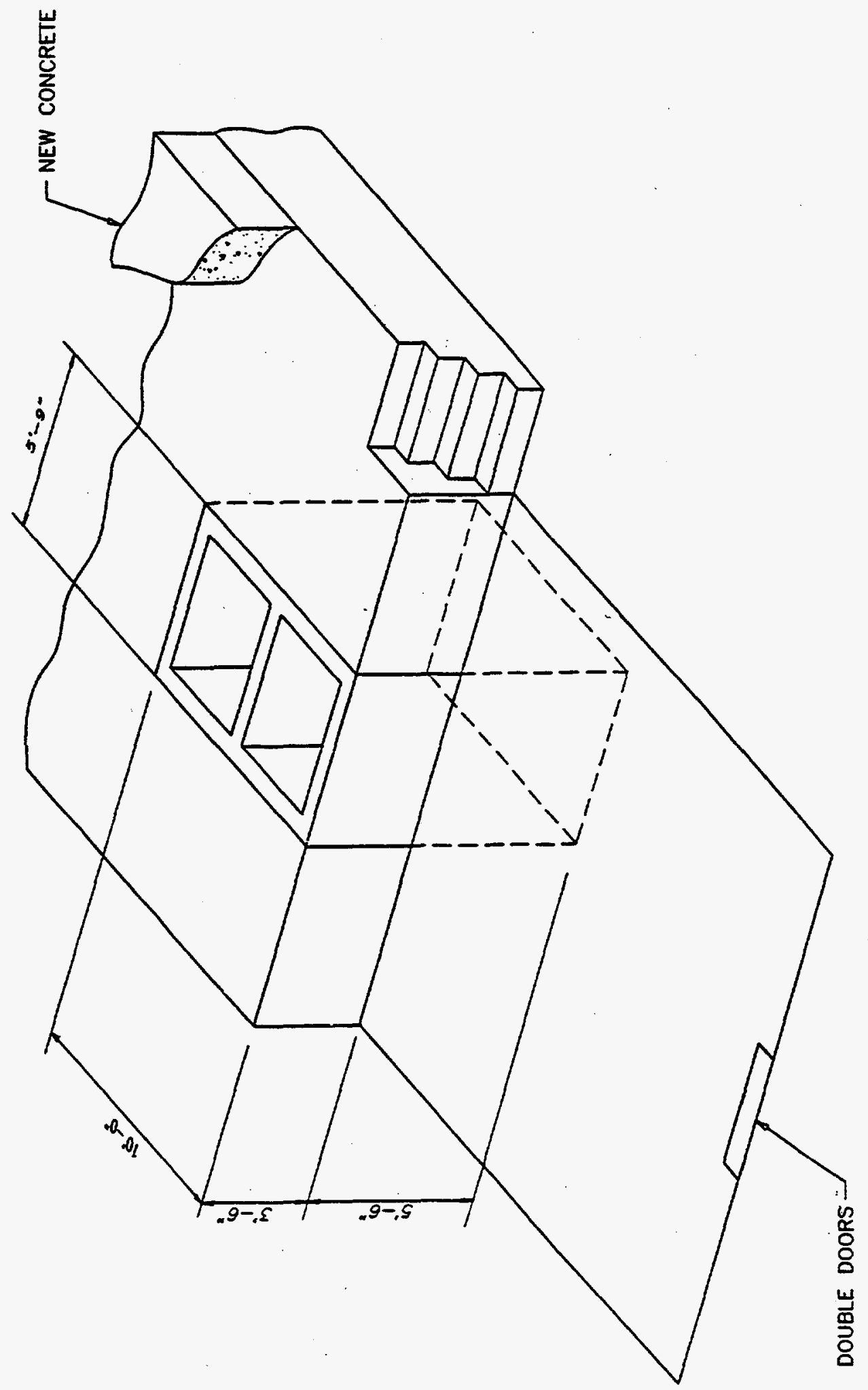




\subsubsection{8-C-4 (105-C) Horizontal Control Rod Cave}

The 105-C Horizontal Control Rod Storage Cave is a reinforced concrete bunker approximately 22-m (70-ft) long, 1-m (3-ft) high, and 1.9-m (12-ft) wide, with triangle-shaped concrete ends $1-\mathrm{m}$ (3-ft) high containing steel doors. The internal structure is probably made of corrugatedsteel culvert material, cut in half, and placed cut-side down to create two internal long, domed structures which lay on a concrete pad. The rod cave is covered with an overlay of 1 to $1.2 \mathrm{~m} \mathrm{(3}$ to $4 \mathrm{ft}$ ) of dirt and gravel. It is currently barricaded and sealed to prevent personnel from entering.

The rod cave was used to store radiologically contaminated control rod tips. The potential exists for stored contaminated reactor parts to be present within this facility. Radioactive contamination is known to be present based on radiation surveys, but the amount and type are unknown.

The rod cave is in good structural condition.

\subsubsection{9-B Exhaust Air Sampler Building}

The current 119-B Exhaust Air Sampler Building is a single-story, wooden-frame structure with wood siding, approximately $3.7 \mathrm{~m}^{2}\left(12 \mathrm{ft}^{2}\right)$, with a corrugated transite roof over a tar and gravel built-up roof. The building sits on a concrete slab. The building was potentially used to store solvents or other petrochemicals. (Note: A prefabricated metal building that has since been removed from the 100-B/C Area was known by the same name. In addition, the current building is identified in some documents as the 1715-B Paint and Storage Building).

Visual inspection of the building has identified evidence of solvent and/or petrochemical contamination. Records of spills or releases of hazardous substances do not exist; however, solvents may be present in the concrete matrix. Evidence of radiological contamination does not exist.

\subsubsection{5-C Reactor (Waste Disposition Only)}

In 1993, a final environmental impact statement was issued under the National Environmental Policy Act of 1969 (NEPA), which evaluated alternatives for decommissioning eight of the nine reactors in the 100 Area of the Hanford Site, including the C Reactor (DOE 1993). The $\mathrm{N}$ Reactor was excluded from this evaluation. The decommissioning alternative selected and documented in the Federal Register (FR) is safe storage, followed by one-piece removal of the reactor block to an onsite low-level waste (LLW) burial area (40 FR 20489, 54 FR 18325, 58 FR 48509). The decision was made after a 90-day public comment period initiated on April 28, 1989. Because the decision on decommissioning of the reactor was made under the NEPA process, reactor block decommissioning is not included in the scope of this EE/CA. However, since the decision made under NEPA does not specify the disposal site for waste generated 


\section{DOE/RL-96-85}

Rev. 0

during safe storage activities, this EE/CA evaluates disposal of wastes generated while placing the reactor block into the safe-storage condition.

Although the only scope of this EE/CA for 105-C is disposition of waste generated during 105-C safe-storage activities, it should be noted that the Washington State Department of Ecology (Ecology), EPA, and RL (Tri-Parties) are currently negotiating milestones for activities associated with removal of the surplus production reactors.

Preparation of the reactor block for storage includes the following:

- Removal of equipment and material from the 105-C Reactor Building

- Decontamination of equipment and structures

- Dismantlement/demolition of structures outside the reactor shield walls

- Construction of a safe storage enclosure utilizing the existing reactor block primary shield and installation of a new roof

- Installation of electrical, mechanical, control, and monitoring systems for use during surveillance

- Restoration of the site, following decommissioning and demolition activities.

The safe-storage enclosure includes filling in any holes in the reactor block primary shield and construction of a new roof over the primary shield walls. Safe-storage activities will also include a series of technical demonstrations for improved technologies in the area of characterization, decontamination, demolition, facility stabilization, health and safety, and waste disposition. In demonstrating these technologies on a large scale, it is believed that they may have a significant benefit over the use of baseline technologies in the following areas:

- Lower facility lifecycle costs

- Lower health and safety risks to the worker and the public

- Lower risks for detrimental impact to the environment

- Reduce amount of secondary waste

- Reduce hazard level and category of waste

- Increase reuse of materials within DOE and /or free release of materials for recycle by the private sector 
DOE/RL-96-85

Rev. 0

- Lower time required for characterization, decontamination, decommissioning, and disposition of facilities

- Reduction of amount of residual contamination in materials following decontamination

- Reduce cost and worker exposure in S\&M of facilities.

Both radioactive and nonradioactive hazardous substances are currently present in the building and will remain within the area of contamination until a disposal alternative is selected.

Removal activities are expected to generate a variety of wastes including inert demolition debris, low-level radioactive waste, dangerous waste, and mixed waste. The 105-C Reactor Building has been characterized by sampling and visual inspection. Table 1 presents an estimate of waste volumes and types to be expected in preparing the facility for safe storage.

Table 1. Waste Generated During 105-C Reactor

Safe-Storage Activities.

\begin{tabular}{|l|c|}
\hline \multicolumn{1}{|c|}{ Waste Type } & Volume, $\mathbf{m}^{\mathbf{3}}$ \\
\hline $\mathrm{ACM}$ & 202 \\
\hline Low-level radioactive waste & 2,220 \\
\hline Dangerous waste & 20 \\
\hline Mixed waste & 9 \\
\hline
\end{tabular}

$\mathrm{ACM}=$ asbestos-containing material.

\subsubsection{8-F Biology Laboratory}

The 108-F Biology Laboratory was constructed in 1944 and was intended to be used as a facility for the mixing and addition of chemicals used in the treatment of the reactor cooling water. Shortly after F Reactor began operation, it was determined that the facility was not needed for this purpose. In 1949, the building was converted for use as a biological laboratory. For the next 24 years, the laboratory was used for life-science studies of the effects of radiologic contamination on plant and animal life relative to man.

The original building is a rectangular four-story, steel framed, concrete block structure with concrete foundation and floors. The building was enlarged in 1950 to provide more space, bringing the total area to about $1,858 \mathrm{~m}^{2}\left(20,000 \mathrm{ft}^{2}\right)$. A newer annex (constructed in 1961), a rectangular three-story addition of concrete block construction (about $1,022 \mathrm{~m}^{2}$ ), adjoins the

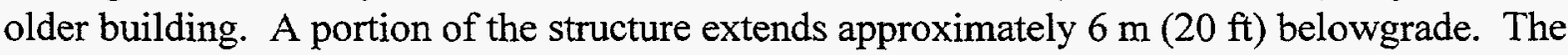
building contained 47 laboratories, a number of small offices, a conference room, administrative section, lunch and locker rooms, and a heavily shielded high-energy exposure cell. Several french drains are located near the building. The french drains are being managed under the waste site remediation program and are not included in the scope of this EE/CA. In 1973, research 
activities at the facility were terminated and loose, readily-accessible radioactive contamination was removed by mechanical means.

According to personnel interviews and historical knowledge, radioactive contamination exists in the first floor concrete trench and sump system, and the potential exists for radioactive contamination in the second floor annex, building air filters, exterior and interior (between rooms or areas) building penetrations, and ductwork. Although the laboratory hoods have been removed, there are several large hood ventilation ducts that may be contaminated. Contaminants identified during decontamination efforts in 1983 included ${ }^{238} \mathrm{Pu},{ }^{239} \mathrm{Pu},{ }^{90} \mathrm{Sr},{ }^{60} \mathrm{Co}$, and ${ }^{137} \mathrm{Cs}$. Mercury was used in the building and may be present in laboratory drains. Because of the age of the facility, polychlorinated biphenyls $(\mathrm{PCB})$ are expected in elevator gear box oils. Lead shielding and counterweights remain within the facility; in addition, the building contains friable asbestos.

The interior of the structure is in poor condition with severe friable asbestos contamination. The exterior is in fair condition. The asphalt-covered roof is in poor condition and shows evidence of heavy leaking.

\subsection{SOURCE, NATURE, AND EXTENT OF CONTAMINATION}

The 100-B/C Area facilities are contaminated by hazardous substances used in or generated by reactor operations. The 108-F Biology Laboratory was contaminated by hazardous substances used in experimentation and the study of the effects of radiation on biota. Facility-specific information on contaminant sources was provided in Section 2.2. A summary of the anticipated nature and extent of this contamination is provided in Table 2.

Unless specific characterization data are available, specification of radioactive contaminants is not indicated in the table. Based on process knowledge, it is expected that most of the radioactive materials which contaminate the facilities are fission products (e.g., $\mathrm{Eu}, \mathrm{Cs}, \mathrm{Sr}, \mathrm{Pu}$, Co).

Likewise, where process knowledge indicates the probable presence for nonradioactive hazardous substances, these are identified by general type rather than specific chemical, unless characterization data are available. Asbestos is identified as a hazardous substance regardless of whether it is currently in a friable or nonfriable condition.

\subsection{SITE CONDITIONS THAT JUSTIFY A REMOVAL ACTION}

The removal site evaluation (BHI 1996) determined that six facilities in the 100-B/C Area and the 108-F Biology Laboratory are either known or suspected to be contaminated with radioactive and/or nonradioactive hazardous substances. Current $S \& M$ activities minimize the potential for release of these substances. Some exposure to personnel providing S\&M for the facilities and to intruding wildlife (e.g., rodents, insects, snakes, and birds) may occur. Some spread of 
contamination also occurs because of contact with and subsequent transfer by personnel and wildlife.

The facilities are continuing to deteriorate as they age. As described in Section 2.2, many of the structural components are in poor condition. As the facilities age, it will be more difficult to maintain confinement of the hazardous substances. This potential for a future release justifies the removal action.

Table 2. Nature and Extent of Potential Hazardous Substance Contamination in the 100-B/C Area Facilities and the 108-F Biology Laboratory.

\begin{tabular}{|c|c|}
\hline Facility & Hazardous Substance \\
\hline 111-B Decontamination Station & $\begin{array}{l}\text { - Radioactive contaminants (including }{ }^{90} \mathrm{Sr},{ }^{137} \mathrm{Cs},{ }^{60} \mathrm{Co},{ }^{155} \mathrm{Eu},{ }^{238} \mathrm{Pu},{ }^{239} \mathrm{Pu} \text { ) } \\
\text {-Concrete pad - } 30,000 \mathrm{cpm} \text { at hot spot. Anticipate high concentrations } \\
\text { in subsurface tanks } \\
\text { - Potential special nuclear materials } \\
\text { - Potential solvents } \\
\text { - Potential sodium dichromate, sodium oxalate, sodium sulfamate }\end{array}$ \\
\hline $\begin{array}{l}\text { 115-B Gas Line Pressure/ Vacuum } \\
\text { Seal House }\end{array}$ & $\begin{array}{l}\text { - Radioactive contaminants (including }{ }^{14} \mathrm{C}^{60}{ }^{60} \mathrm{Co},{ }^{137} \mathrm{Cs},{ }^{90} \mathrm{Sr} \text {, } \\
{ }^{15 s},{ }^{152} \mathrm{Eu},{ }^{154} \mathrm{Eu},{ }_{155} \mathrm{Eu},{ }^{238} \mathrm{Pu},{ }^{239 / 240} \mathrm{Pu} \text { ) } \\
\text {-Surveys indicate } 200-15,000 \mathrm{cpm} \text { in ducting } \\
\text {-Potential dose rates to } 1 \mathrm{mR} / \mathrm{hr} \\
\text { - Mercury (in gauges) } \\
\text { - Potential lead (as shielding) }\end{array}$ \\
\hline $\begin{array}{l}\text { 118-C-4 Horizontal Control Rod } \\
\text { Storage Cave }\end{array}$ & $\begin{array}{l}\text { - Radioactive contaminants } \\
\text { - Potential lead and lead oxide }\end{array}$ \\
\hline $\begin{array}{l}\text { 119-B Exhaust Air Sampler } \\
\text { Building }\end{array}$ & $\begin{array}{l}\text { - Asbestos (in transite) } \\
\text { - Potential solvents }\end{array}$ \\
\hline 105-C Reactor Building & $\begin{array}{l}\text { - Radioactive contaminants } \\
\text {-Twenty nine areas detected with exposure rates in excess of } 10 \text { times } \\
\text { background; moderate to high intensity fields exist. } \\
\text {-Most rooms }<2,000 \mathrm{dpm} \text { alpha, }<1,000 \mathrm{beta} / \text { gamma, and }<2 \mathrm{mrem} / \mathrm{hr} \text {; } \\
\text { range to }>100 \mathrm{mrem} / \mathrm{hr} \text { and }<1,000 \mathrm{mrem} / \mathrm{hr} \text {, with hot spots higher, } \\
\text { such as in piping and ducting; some areas not surveyed due to high } \\
\text { radiation fields. } \\
\text { - Lead (as solids, oxides, and in paint) } \\
\text { - Mercury (in gauges, switches, and drains) } \\
\text { - PCBs (in light ballasts and gear oil) } \\
\text { - Miscellaneous chemicals } \\
\text { - Asbestos (as pipe lagging, other insulation, and in transite) }\end{array}$ \\
\hline 108-F Biology Laboratory & $\begin{array}{l}\text { - Radioactive contaminants (including }{ }^{238} \mathrm{Pu},{ }^{239} \mathrm{Pu},{ }^{90} \mathrm{Sr},{ }^{60} \mathrm{Co} \text {, and }{ }^{137} \mathrm{Cs} \text { ) } \\
\text { - Potential mercury (in laboratory drains) } \\
\text { - PCBs (in light ballasts and gear oils) } \\
\text { - Lead (as solid, oxide and in paint) } \\
\text { - Asbestos (pipe lagging, other insulation) }\end{array}$ \\
\hline
\end{tabular}

$\mathrm{cpm}=$ counts per minute.

$\mathrm{dpm}=$ disintigrations per minute.

mrem $=$ millirem per hour . 
DOE/RL-96-85

Rev. 0 
DOE/RL-96-85

Rev. 0

\subsection{REMOVAL ACTION OBJECTIVES}

Removal action objectives to protect human health and the environment include the following components:

- $\quad$ Reduce the threat of release of hazardous substances contained within buildings and structures

- $\quad$ Protect workers from hazards posed by these facilities

- $\quad$ Minimize or eliminate S\&M requirements and associated costs

- Facilitate and be consistent with future remediation for the areas in which the facilities are located.

The scope of this removal action is limited to the six facilities identified in Section 2.0. The principal threats to be addressed are contaminated materials and contaminated surfaces of these facilities. Uncontaminated structures or portions of structures associated with the facilities within this scope may be removed or otherwise addressed as necessary to facilitate implementation of the selected removal action.

The waste sites (118-C-2, 116-C-2B, 116-C-2C, 132-C-1, 100-C-3 and 132-C-3) listed in the Waste Information Data System (owned and operated by Fluor Daniel Hanford, Inc.), and the $100-\mathrm{BC}-1$ and $100-\mathrm{BC}-2$ operable units that are within the vicinity of the 105-C Reactor Building Safe Storage activity may be remediated to accommodate completion of the safe-storage activity. The cleanup activity will be conducted in accordance with the standards and cleanup levels provided in the 100-BC-1, 100-DR-1 and 100-HR-1 ROD. Contaminated and uncontaminated soil may be moved or removed as necessary to implement the removal action for the structures, and the cleanup levels specified in the 100-BC-1, 100-DR-1, and 100-HR-1 ROD (EPA 1995b) will be met. Verification sampling will be performed after the buildings have been removed. This sampling will be consistent with the 100-BC-1, 100-DR-1, and 100-HR-1 Sampling and Analysis Plan which has been approved by EPA and Ecology (DOE 1996b). The verification sampling results will be submitted to EPA/Ecology for their concurrence.

Further evaluation of remaining subsurface structures and contaminated soils, and (if necessary) remediation of those structures and soils, would be performed in accordance with the process established for CERCLA waste sites in the following: Tri-Party Agreement (Ecology et al. 1990); ROD (EPA 1995b); sampling and analysis plan for the 100-BC-1, DR-1 and HR-1 operable units (DOE 1996b); and the Remedial Design Report/Remedial Action Work Plan for 100 Area (DOE 1996a). The evaluation and remediation are beyond the scope of this EE/CA.

Field activities for the removal action for the facilities and remediation of the source operable unit will be coordinated as necessary with the remedial action activities in DOE (1996a). 
Rev. 0

The removal action schedule will be based on risk minimization and budget constraints. In general, facilities that present the greatest risk to workers and potentially to the public are addressed first. Relative risk will be assessed based on the degree of contamination, condition of the facility, and the potential for a release. Budget considerations will first focus on those facilities that require more maintenance (thus higher costs) to ensure continued confinement and safety. 
Rev. 0

\subsection{IDENTIFICATION OF REMOVंAL ACTION ALTERNATIVES}

There are four alternatives proposed for this action:

1. No action

2. Continued S\&M

3. Decontamination, demolition, and disposal at the Environmental Restoration Disposal Facility (ERDF)

4. Decontamination, demolition, and disposal at other Hanford Site facilities.

\subsection{NO ACTION}

Under the no-action alternative, access to the facility would be restricted but no action would occur to address the hazards posed by the facility. The 100 Area facilities would continue to deteriorate. Without any active $S \& M$, the rate of deterioration will accelerate. Although Hanford Site 100 Area institutional controls would continue to help prevent personnel or worker entry to the facility, releases of contaminants from the facility would ultimately occur. The cost for this alternative would be negligible.

\subsection{CONTINUED SURVEILLANCE AND MAINTENANCE}

Under this alternative, the facilities addressed by this EE/CA would be maintained in their current condition. The current level of S\&M would be performed to minimize the potential for environmental release, protect workers, and maintain compliance with state and federal regulations and DOE orders. Contaminated materials and surfaces would remain in place. As the facilities continue to age and deteriorate, it is expected that maintenance requirements necessary to continue safe and environmentally protective conditions would increase.

The individual and cumulative costs to continue S\&M are provided in Table 3. 
DOE/RL-96-85

Rev. 0

Table 3. Cost Estimates: Continued Surveillance and Maintenance.

\begin{tabular}{|l|r|}
\hline \multicolumn{1}{|c|}{ Facility } & \multicolumn{1}{|c|}{ Estimated Costs $^{\mathrm{a}}$} \\
\hline 111-B Decontamination Station & $\$ 1,500.00$ \\
\hline 115-B Gas Line Pressure/Vacuum Seal House & 870.00 \\
\hline 118-C-4 105-C Horizontal Control Rod Cave & $2,300.00$ \\
\hline 119-B Exhaust Air Sampler Building & 170.00 \\
\hline 105-C Long-Term Safe Storage & $\mathrm{N} / \mathrm{A}^{\mathrm{b}, \mathrm{c}}$ \\
\hline 108-F Biology Laboratory & $187,000.00$ \\
\hline Total & $191,840.00$ \\
\hline
\end{tabular}

${ }^{2}$ Costs are on an annual basis. Total costs for this alternative would depend on the number of years of $S \& M$ prior to initiation of decommissioning. If $S \& M$ is performed over the next 10 years, a total cost of approximately $\$ 2$ million is incurred. Even with continued $S \& M$, the facilities will eventually require decommissioning with additional future costs incurred consistent with Tables 4 and 5 .

${ }^{b}$ This EE/CA only addresses disposal of wastes from 105-C safe-storage preparation activities; however, the total annual cost of S\&M, authorized by the surplus productions reactors Environmental Impact Statement, is $\$ 200,000$ provided for information purposes.

${ }^{c}$ Additional $\$ 1,500,000$ for roof installation.

\subsection{DECONTAMINATION, DECOMMISSIONING, AND DISPOSAL AT THE ENVIRONMENTAL RESTORATION DISPOSAL FACILITY}

This alternative consists of three components: decontamination, demolition, and disposal. Decontamination would consist of either physically removing contaminants or "fixing" contaminants in place to prevent mobility during demolition. Standard methods of physical removal include washing with water (possibly containing detergent), scraping, scabbling, and sandblasting. In some instances, physical removal of contaminants may not be feasible or cost effective. In these cases, the contamination may be "fixed" so it remains relatively well attached to the construction materials or so it is less readily disturbed during subsequent demolition activities. Examples of fixing contaminants in place include painting, applying asphalt, and spreading plastic sheeting.

Decontamination would be performed to the extent that such decontamination is feasible and satisfies one or more of the following needs:

- Worker safety: In some cases, surface decontamination is either necessary or desirable to minimize worker exposure to contaminants during demolition. 
Air emissions: Decontamination may be required to ensure that fugitive emissions during demolition do not exceed applicable air standards, and to meet requirements for using best available control technologies.

- Waste minimization: In some cases, decontamination of surfaces can result in substantial reductions in contaminated waste volumes.

- Cost-effectiveness: Decontamination prior to demolition can reduce the level of protection required during demolition and waste volumes, and thus reduce overall removal costs.

Demolition would involve actual destruction of the structure as necessary to meet applicable or relevant and appropriate requirements (ARAR) specified in this EE/CA and the ARARs specified in the 100-BC-1, 100-DR-1, and 100-HR-1 ROD. Demolition of clean structures normally occurs to a depth of up to $1 \mathrm{~m}(3 \mathrm{ft}$ ) belowgrade. Demolition may be preceded by dismantlement of facility components, such as severing and removing ductwork or selectively removing a facility wall or structure. Demolition itself generally means large-scale facility destruction using a wrecking ball, explosives, or other industrial methods. Demolition techniques would be designed to allow building materials to be recycled when possible.

Rubble generated during demolition would be segregated by material type (e.g., wood, concrete, metal) and evaluated for contamination. Sampling and analysis would be performed as necessary to facilitate this evaluation. Materials that are not contaminated or that can be cost-effectively decontaminated would be reused or recycled to the extent possible. Materials that are contaminated and for which no reuse, recycle, or decontamination option is identified would be assigned an appropriate waste designation (e.g., solid, radioactive, dangerous, mixed). Wastes that are designated as radioactive, dangerous, or mixed waste would be transported to the ERDF in the 200 West Area of the Hanford Site for disposal. The ERDF is designed to be an isolation structure for long-term disposal of wastes generated from Hanford Site CERCLA activities. Construction and operation of the ERDF were authorized via a separate ROD and are not within the scope of this EE/CA (EPA 1995a). Disposal of waste generated during decommissioning activities is authorized by the DOE ERDF Explanation of Significant Differences (EPA et al. 1996). The ERDF is designed to meet Resource Conservation and Recovery Act of 1976 (RCRA) minimum technological requirements for landfills, including standards for a double liner, a leachate collection system, leak detection, and final cover. Waste may be treated as necessary to meet the ERDF waste acceptance criteria (Roeck 1996) or minimize volumes (e.g., by crushing, sizing, sorting, etc.). Uncontaminated demolition rubble that cannot be recycled would be disposed in one of the inert waste landfills on the Hanford Site or other designated rubble pits approved for disposal of this material (EPA et al. 1996).

Both low-level radioactive and nonradioactive liquid wastes may be encountered or generated during decommissioning. Radioactive solutions would be packaged and transported to the Hanford Site Effluent Treatment Facility or other Hanford Site facilities for treatment and disposal in full compliance with applicable regulations. Small amount of liquids may be treated or stabilized (to meet applicable waste acceptance criteria) and sent to the ERDF for disposal. If transuranic waste above ERDF waste acceptance criteria (Roeck 1996) is encountered, it will be 
transported to the Transuranic Waste Storage and Assay Facility or Central Waste Complex in the 200 Area of the Hanford Site for storage. Nonradioactive liquids contaminated with hazardous constituents would be packaged and shipped to an offsite-permitted facility for treatment and disposal in full compliance with all applicable regulations, or treated/stabilized and sent to ERDF. Sampling and analysis plans, for the purpose of waste designation, will be submitted to EPA/Ecology for approval.

The individual and cumulative costs and schedules for this alternative are shown in Table 4.

\subsection{DECONTAMINATION AND DEMOLITION (OTHER HANFORD FACILITY DISPOSAL)}

This alternative would be identical to the third alternative except for the location of waste disposal. Low-level radioactive wastes would be disposed at the LLBG located in the 200 Area of the Hanford Site. The LLBG are unlined trenches in which low-level radioactive waste is placed and covered with soil. Dangerous wastes that are not radioactive would be packaged and transported to an offsite-permitted hazardous waste disposal facility. Any offsite facility would be required to meet all requirements for RCRA dangerous waste disposal including double-liner, leachate collection, and cover and be authorized to accept CERCLA offsite waste. Mixed wastes would be disposed at the W-025 Mixed Waste Trench (W-025) located in the 200 West Area. W-025 is an onsite RCRA-permitted disposal facility that is constructed with double liner, leachate collection and monitoring, and cover. Costs and schedules for this alternative are provided in Table 5. 
Rev. 0

Table 4. Environmental Restoration Disposal Facility.

\begin{tabular}{|c|c|c|c|c|c|c|}
\hline \multirow[b]{2}{*}{ Facility } & \multirow{2}{*}{$\begin{array}{c}\text { Estimated } \\
\text { D\&D }\end{array}$} & \multicolumn{2}{|c|}{ D\&D Schedule } & \multirow[b]{2}{*}{ Waste Volumes ${ }^{b}$} & \multirow{2}{*}{$\begin{array}{l}\text { Disposal } \\
\text { Cost }^{\text {a, c }}\end{array}$} & \multirow[b]{2}{*}{ Total Cost } \\
\hline & & $\begin{array}{c}\text { Duration } \\
\text { months }\end{array}$ & Completion $^{\mathrm{e}}$ & & & \\
\hline $\begin{array}{l}\text { 111-B } \\
\text { Decontamination } \\
\text { Station } \\
\end{array}$ & $\$ 834,000.00$ & 34 & Sep. 1999 & $\begin{array}{l}\text { Dangerous waste }=2 \mathrm{~m}^{3} \\
\mathrm{ACM}=46 \mathrm{~m}^{3} \\
\mathrm{LLW}=33 \mathrm{~m}^{3}\end{array}$ & $\begin{array}{l}\$ 156.00 \\
1,380.00 \\
2,574.00\end{array}$ & $\$ 838,110.00$ \\
\hline $\begin{array}{l}\text { 115-B Gas Line } \\
\text { Pressure/Vacuum Seal } \\
\text { House }\end{array}$ & $53,000.00$ & 16 & May 1998 & $\mathrm{LLW}=17 \mathrm{~m}^{3}$ & $1,330.00$ & $54,330.00$ \\
\hline $\begin{array}{l}118-C-4105-C \\
\text { Horizontal Control } \\
\text { Rod Cave }\end{array}$ & $347,000.00$ & 32 & June 1998 & $\begin{array}{l}\text { Dangerous waste }=0.2 \mathrm{~m}^{3} \\
\mathrm{ACM}=4 \mathrm{~m}^{3} \\
\mathrm{LLW}=25 \mathrm{~m}^{3}\end{array}$ & $\begin{array}{r}16.00 \\
120.00 \\
1,950.00\end{array}$ & $349,090.00$ \\
\hline $\begin{array}{l}\text { 119-B Exhaust Air } \\
\text { Sampler Building }\end{array}$ & $163,000.00$ & 8 & Sep. 1998 & $\mathrm{ACM}=.34 \mathrm{~m}^{3}$ & 10.00 & $163,010.00$ \\
\hline $\begin{array}{l}\text { 105-C Long-Term } \\
\text { Safe Storage }\end{array}$ & $N / A^{d}$ & 42 & Sep. 1998 & $\begin{array}{l}\mathrm{LLW}=2,200 \mathrm{~m}^{3} \\
\text { Dangerous waste }=20 \mathrm{~m}^{3} \\
\text { Mixed }=9 \mathrm{~m}^{3} \\
\mathrm{ACM}=202 \mathrm{~m}^{3}\end{array}$ & $\begin{array}{r}171,600.00 \\
1,560.00 \\
700.00 \\
6,060.00 \\
\end{array}$ & $179,920.00$ \\
\hline $\begin{array}{l}\text { 108-F Biology } \\
\text { Laboratory }\end{array}$ & $3,849,000.00$ & 39 & Sep. 1999 & $\begin{array}{l}\text { LLW }=3 \mathrm{~m}^{3} \\
\mathrm{ACM}=606 \mathrm{~m}^{3}\end{array}$ & $\begin{array}{r}234.00 \\
18,180.00\end{array}$ & $3,867,410.00$ \\
\hline TOTAL & $\$ 5,246,000.00$ & - & - & - & & $5,461,870.00$ \\
\hline
\end{tabular}

${ }^{a}$ Disposal cost assumptions: Disposal of low-level radioactive, dangerous, and mixed wastes at the ERDF at $\$ 78 \mathrm{~m}^{3}\left(\$ 60 \mathrm{yd}^{3}\right)$. Includes all direct and indirect costs and cost of transportation from area to ERDF.



${ }^{\mathrm{C}} \mathrm{ACM}$ is assumed to be noncontaminated and disposed at the Basin Disposal Facility in Pasco, Washington at $\$ 30 \mathrm{~m}^{3}$ (\$23 $\left.\mathrm{yd}^{3}\right)$.

${ }^{\mathrm{d}}$ This EE/CA only addresses disposal of wastes from $105-\mathrm{C}$ safe storage preparation activities. For information purposes only, the total cost for performing safe storage, as authorized by the Surplus Production Reactors EIS, is $\$ 18,379,920$.

${ }^{e}$ Completion date entails issuance of the final report, not removal of the facility. Facility removal usually occurs a few months before the final report is issued. 
DOE/RL-96-85

Rev. 0

Table 5. Other Hanford Sites.

\begin{tabular}{|c|c|c|c|c|c|c|}
\hline \multirow[b]{2}{*}{ Facility } & \multirow{2}{*}{$\begin{array}{l}\text { Estimated } \\
\text { D\&D }\end{array}$} & \multicolumn{2}{|c|}{ D\&D Schedule } & \multirow[b]{2}{*}{ Waste Volumes ${ }^{b}$} & \multirow{2}{*}{$\begin{array}{l}\text { Disposal } \\
\text { Cost }^{a, c}\end{array}$} & \multirow[b]{2}{*}{ Total Cost } \\
\hline & & $\begin{array}{c}\text { Duration } \\
\text { months }\end{array}$ & Completion $^{\mathrm{e}}$ & & & \\
\hline $\begin{array}{l}111-\mathrm{B} \\
\text { Decontamination } \\
\text { Station }\end{array}$ & $\$ 834,000.00$ & 34 & March 1998 & $\begin{array}{l}\mathrm{ACM}=46 \mathrm{~m}^{3} \\
\text { Dangerous waste }=2 \\
\mathrm{~m}^{3} \\
\mathrm{LLW}=33 \mathrm{~m}^{3}\end{array}$ & $\begin{array}{l}\$ 1,380.00 \\
10,160.00 \\
18,249.00\end{array}$ & $\$ 863,790.00$ \\
\hline $\begin{array}{l}\text { 115-B Gas Line } \\
\text { Pressure/Vacuum } \\
\text { Seal House }\end{array}$ & $53,000.00$ & 16 & April 1997 & $L L W=17 \mathrm{~m}^{3}$ & $9,401.00$ & $62,400.00$ \\
\hline $\begin{array}{l}\text { 118-C-4 105-C } \\
\text { Horizontal Control } \\
\text { Rod Cave }\end{array}$ & $347,000.00$ & 32 & Jan. 1998 & $\begin{array}{l}\mathrm{ACM}=4 \mathrm{~m}^{3} \\
\text { Dangerous waste }=0.2 \\
\mathrm{~m}^{3} \\
\mathrm{LLW}=25 \mathrm{~m}^{3}\end{array}$ & $\begin{array}{r}120.00 \\
1,015.00 \\
13,825.00\end{array}$ & $361,960.00$ \\
\hline $\begin{array}{l}\text { 119-B Exhaust Air } \\
\text { Sampler Building }\end{array}$ & $163,000.00$ & 8 & June 1997 & $\mathrm{ACM}=0.34 \mathrm{~m}^{3}$ & 10.00 & $163,010.00$ \\
\hline $\begin{array}{l}\text { 105-C Long-Term } \\
\text { Safe Storage (waste } \\
\text { disposal only) }\end{array}$ & $N / A^{d}$ & 42 & July 1998 & $\begin{array}{l}\mathrm{LLW}=2,200 \mathrm{~m}^{3} \\
\text { Dangerous }=20 \mathrm{~m}^{3} \\
\text { Mixed }=9 \mathrm{~m}^{3}\end{array}$ & $\begin{array}{r}1,216,600.00 \\
101,600.00 \\
45,720.00\end{array}$ & $1,363,920$ \\
\hline $\begin{array}{l}\text { 108-F Biology } \\
\text { Laboratory }\end{array}$ & $3,849,000.00$ & 39 & May 1999 & $\begin{array}{l}L L W=3 \mathrm{~m}^{3} \\
A C M=606 \mathrm{~m}^{3}\end{array}$ & $\begin{array}{r}1,660.00 \\
18,180\end{array}$ & $3,868,840.00$ \\
\hline TOTAL & $\$ 5,246,000.00$ & - & -- & - & & $6,683,920.00$ \\
\hline
\end{tabular}

${ }^{a}$ Disposal cost assumptions: Transportation costs $\$ 13 / \mathrm{m}^{3}\left(10 \mathrm{yd}^{3}\right)$. Disposal of low-level radioactive waste at LLBG at $540 \mathrm{~m}^{3}$ ( $\$ 412 \mathrm{yd} 3$ ) and disposal of dangerous or radioactive mixed waste onsite at $\$ 5,080 / \mathrm{m} 3$ ( $\$ 3,890 \mathrm{yd} 3)$. The mixed waste costs include interim storage at the Central Waste Complex until the mixed waste disposal trench (W-025) opens for waste receipts..

${ }^{\mathrm{b}} \mathrm{ACM}$ assumed to be noncontaminated and will be disposed at the Basin Disposal Facility in Pasco, Washington at $\$ 30 \mathrm{~m}^{3}(\$ 20$ $\left.\mathrm{yd}^{3}\right)$.

${ }^{c}$ Inert (nondangerous) demolition waste and costs not included.

${ }^{\mathrm{d}}$ This EE/CA only addresses disposal of wastes from 105-C safe storage preparation activities. For information purposes only, the total cost for performing safe storage, as authorized by the Surplus Production Reactors EIS, is $\$ 18,200,000$.

${ }^{e}$ Completion date entails issuance of the final report, not removal of the facility. Facility removal usually occurs a few months before the final report is issued. 
DOE/RL-96-85

Rev. 0

\subsection{COMPARATIVE ANALYSIS OF ALTERNATIVES}

CERCLA requires that the remedial action alternatives be evaluated against nine criteria (at the Hanford Site the nine criteria evaluation is also performed for removal actions):

1. Overall protection of human health and the environment

2. Compliance with federal and state laws and regulations

3. Long-term effectiveness and permanence

4. Reduction of toxicity, mobility, or volume through treatment

5. Short-term effectiveness

6. Implementability

7. Cost

8. State acceptance

9. Community acceptance.

\subsection{OVERALL PROTECTION}

This criterion evaluates whether the alternative achieves adequate overall elimination, reduction, or control of risks to human health and the environment posed by the likely exposure pathways. Reducing the potential threat to acceptable levels is a threshold requirement and is the primary objective of the removal action.

The no-action alternative provides no additional protection of human health and the environment. S\&M activities will cease, resulting in expedited deterioration of the facilities and maximizing the threat of release.

Continued S\&M provides no additional protection of human health and the environment, except by decay of radioactive contaminants over a long period of time. The facilities will continue to age, and maintaining sufficient integrity to minimize the threat of a release and protect workers will become increasingly difficult.

All of the demolition alternatives provide overall protection of human health and the environment in accordance with the cleanup goals identified for the removal action. Implementing any of these alternatives would remove contaminated materials from the 100 Area and eliminate the primary exposure pathway, release from above-ground structures. In alternative two, dangerous and mixed wastes would be placed in an engineered double-lined facility designed to reduce the threat that contaminants will enter the environment. In the fourth alternative, low-level radioactive waste would be placed in an unlined burial ground with offsite shipment of hazardous waste. The burial grounds are adequately protective for the waste but somewhat less protective than the engineered facility. 
DOE/RL-96-85

Rev. 0

\subsection{COMPLIANCE WITH APPLICABLE OR RELEVANT AND APPROPRIATE REQUIREMENTS}

ARARs are standards, requirements, criteria, or limitations promulgated under federal or state environmental laws that must be met or waived for actions conducted under CERCLA. Only the substantive provisions of requirements that are ARARs must be met (or waived) for actions conducted entirely onsite (CERCLA Section 121[d][2]); however, such onsite actions are exempted from obtaining federal, state, and local permits (CERCLA Section 121[e][1]).

The no-action alternative invokes no ARARs that need to be satisfied. Under the no-action alternative, hazardous substances would remain at the facilities, and the facilities would be allowed to deteriorate over time.

Both demolition alternatives would occur in proximity to the Columbia River, in an area that has the potential to be culturally and ecologically sensitive, and at facilities that may be historically sensitive. These alternatives would have the potential to generate wastes, wastewater, and air emissions. The major ARARs pertinent to these alternatives are standards for protection of the Columbia River, cultural, and ecological resource protection requirements, waste and wastewater management standards, air emission standards, and radiation protection standards. ARARs for the remediation of soils and subsurface structures, associated with liquid waste disposal sites, are identified in the 100-BC-1, 100-DR-1, and 100-HR-1 ROD (EPA 1995b) and will be followed and met during decommissioning activities discussed in this EE/CA, as appropriate. The following sections outline the ARARs identified in the 100-BC-1, DR-1, HR-1 ROD.

\subsubsection{Chemical -Specific ARARs}

- $\quad$ Safe Drinking Water Act, 40 U.S.C Section 300

- "Model Toxics Control Act Cleanup Regulations" (MTCA), Washington Administrative Code (WAC) 173-340

- $\quad$ Clean Water Act, 33 U.S.C Section 1251

- "Water Quality Standards for Water of the State of Washington," WAC 173-201-035

- "National Primary and Secondary Ambient Air Quality Standards," 40 CFR 50

- "National Emissions Standards for Hazardous Air Pollutants," 40 CFR 61.

\subsubsection{Action-Specific ARARs}

- $\quad$ MTCA, WAC 173-340

- "State of Washington Dangerous Waste Regulations," WAC 173-303 
DOE/RL-96-85

Rev. 0

- $\quad$ RCRA Subtitle C, 40 CFR 261, 264, 268

- "U.S. Department of Transportation Requirements for the Transportation of Hazardous Materials," 49 CFR 100-179

- Hazardous Materials Transportation Act, 49 U.S.C 1801-1813

- "RCRA Land Disposal Restrictions," 40 CFR 268

- "Minimum Standards for Construction and Maintenance of Wells," WAC 173-160 and 162

- "RCRA Standards for Miscellaneous Treatment Units," 40 CFR 264, Subpart X

- "RCRA Standards for Tank Systems Units," 40 CFR Subpart J

- "State of Washington, Department of Health," WAC 246-247.

\subsubsection{Location-Specific ARARs}

- National Archeological and Historical Preservation Act, 16 U.S.C Section 469 and 36 CFR 65

- $\quad$ National Historic Preservation Act, 16 U.S.C 470, et seq. and 36 CFR 800

- $\quad$ Endangered Species Act of 1973, 16 U.S.C 1531, et. seq., and 50 CFR 200 and 402.

\subsubsection{Other Criteria, Advisories, or Guidance to be Considered}

- "Draft Proposed Rulemaking by EPA for Cleanup of Radionuclides in Soils," 40 CFR 196

- . "Draft Proposed Rulemaking by Nuclear Regulatory Commission for Cleanup of Radionuclides in Soils," 10 CFR 20

- $\quad$ ERDF's waste acceptance criteria (Roeck 1996)

- "Radiation Protection Guidance for Exposure to the General Public," 59 FR 66414

- The Future For Hanford: Uses and Cleanup, The Final Report of the Hanford Future Sites Uses Working Group, December 1992. 
DOE/RL-96-85

Rev. 0

Continued S\&M invokes the same ARARs as the two decommissioning alternatives, except for the following:

- $\quad$ ARARs identified in the 100-BC-1, 100-DR-1, and 100-HR-1 ROD (EPA 1995b)

- Columbia River protection standards

- Asbestos.

\subsubsection{Columbia River Protection Standards}

The 40 CFR 122 addresses technology-based limitations and standards, control of toxic pollutants, and monitoring for discharges to waters of the United States, including stormwater. Public Law 100-605, Study of the Hanford Reach of the Columbia River, requires new activities near the Columbia River to minimize direct and adverse effects on the values for which the Columbia River is under study.

No wastewater discharges to the Columbia River are planned under any of the alternatives. Erosion and stormwater controls would be used as necessary in site demolition. A stormwater management plan would be prepared to prevent discharges of contaminated stormwater to the Columbia River.

\subsubsection{Cultural and Ecological Resource Protection Standards}

The National Historic Preservation Act of 1966 (implemented via 36 CFR 800) requires federal agencies to consider the effect of an activity on any significant cultural resource. The Archeological and Historical Preservation Act of 1974 requires action to recover and preserve artifacts in areas where activity may cause irreparable harm, loss, or destruction of significant artifacts.

The cultural resource protection requirements apply because of the presence of potentially significant archeological sites or artifacts in the $100-\mathrm{B} / \mathrm{C}$ and $100-\mathrm{F}$ Areas, and the potential historical significance of facilities in these areas. Cultural reviews are currently being performed for the facilities in the 100-B/C Area to determine whether the buildings are eligible for inclusion on the National Register of Historic Places. The 108-F Biology Laboratory has been recommended as eligible for listing on the register. Appropriate mitigation measures would be taken for the 108-F building and any other facilities found to be eligible for listing on the register. It is unlikely that archeological sites would be impacted by the demolition activities.

The Endangered Species Act of 1973 (implemented via 50 CFR 402) and WAC 232-12-297 prohibit activities that threaten the continued existence of listed species or destroy critical habitat. The Migratory Bird Treaty Act makes it illegal to take, capture, or kill (as applicable) any migratory bird, including the nests and eggs.

Threatened and endangered species are known to be present in the 100 Area but no adverse impacts on protected species or critical habitat from any of the alternatives is anticipated. 
Facility-specific ecological reviews will be conducted prior to the demolition of any facility to identify potential adverse impacts.

\subsubsection{Waste Management Standards}

WAC 173-304 requires the identification and appropriate management of solid wastes that are not dangerous wastes. WAC 173-303 requires the identification and appropriate management of dangerous wastes. WAC 173-216 establishes requirements for discharges to waters in the state, including effluent discharges to the soil column. The 10 CFR 61, Subpart C identifies performance objectives for land disposal facilities of radioactive waste containing byproduct, source, and special nuclear materials.

Demolition under alternatives three and four would generate solid wastes that may be designated as low-level radioactive, dangerous, or mixed wastes. Decontamination under the second and third alternatives may also generate contaminated wastewater from surface washing. All removal action wastes would be evaluated and managed in compliance with the appropriate waste designation. At this time, no listed dangerous wastes are expected to be generated as a result of this action. Wastes designated as characteristic wastes may be generated and would be subject to the dangerous waste management standards in WAC 173-303. The third alternative would meet these standards by disposing of the dangerous or mixed waste at ERDF. Under the fourth alternative, these standards would be met by disposing of dangerous waste at an offsite RCRA-permitted facility and mixed waste at W-025. Low-level radioactive or mixed wastes are likely to be generated and the standards of 10 CFR 61 Subpart C, although not applicable to radioactive-contaminated debris, would be relevant and appropriate. These standards would be met under all of the alternatives by disposal at the ERDF or the LLBG.

\subsubsection{Air Emission Standards}

Under 40 CFR 61, Subpart H and WAC 246-247, radionuclide airborne emissions from all combined operations at the Hanford Site may not exceed $10 \mathrm{mrem} /$ year effective dose equivalent to the hypothetical offsite maximally exposed individual. WAC 246-247 requires verification of compliance, typically through periodic confirmatory air sampling. WAC 173-400 establishes requirements for the control and/or prevention of the emission of air contaminants, including dust.

The radionuclide emission standards would apply to any fugitive, diffuse, and point-source air emissions of radionuclides generated during decontamination and demolition activities under any of the alternatives. If there is the potential for any non-zero radioactive emissions, best available radionuclide control technology would be required. If the action would generate an increase of toxic air pollutants to the atmosphere above the small quantity emission rates, implementation of best available control technology for toxics would be required. The third and fourth alternatives propose to use decontamination of surface contaminants and standard construction techniques to provide dust control during demolition. These methods should adequately control fugitive emissions of radionuclides and toxic air pollutants, and would therefore be considered best 
available radionuclide control technology and best available control technology for toxics for the proposed activities.

\subsubsection{Radiation Protection Standards}

The 10 CFR 835, "Occupational Radiation Protection," establishes radiation protection standards, limits, and program requirements for protecting individuals form ionizing radiation resulting from the conduct of $\mathrm{DOE}$ activities. It also requires that measures be taken to maintain radiation exposure as low as reasonably achievable (ALARA). This regulation is applicable to activities considered under the four alternatives.

A combination of personal protective equipment, personnel training, physical design features (e.g., confinement, remote handling), and administrative controls (e.g., limiting time in radiation zones) would be used to ensure that the requirements of 10 CFR 835 are met under the third and fourth alternative. The third and fourth alternatives would also meet the requirements for exposure ALARA by decontaminating surfaces prior to demolition. The radiation exposure standards in the regulation would be met under the fourth alternative, although more extensive personal protective equipment, training, and administrative controls would be required. However, the fourth alternative would not meet the performance standard for exposure ALARA because it does not include decontamination prior to demolition. For all alternatives, individual monitoring would be performed as necessary to verify compliance with the requirements.

\subsubsection{Polychlorinated Biphenyls}

The Toxic Substances Control Act (TSCA) regulates the management and disposal of PCBs and PCB waste. Implementing regulations in 40 CFR 761 contain requirements for the management of spills and cleanup of materials suspected to contain PCB waste. The ERDF is authorized to accept certain PCB waste for disposal. All waste suspected to contain PCBs will be evaluated to determine whether it meets the ERDF waste acceptance criteria (Roeck 1996). Any PCB waste that does not meet the ERDF Waste Acceptance Criteria will be sent to a PCB storage area that meets the substantive requirements of TSCA, and will be transported for disposal at a TSCAapproved disposal facility.

\subsubsection{Asbestos}

Removal and disposal of asbestos and ACM is regulated under the Clean Air Act (40 CFR 61, Subpart M) and the Occupational Safety and Health Administration (29 CFR 1910.1101 and WAC 296-62). These regulations provide for special precautions to prevent exposure of workers or airborne emissions of asbestos fibers during removal actions. All of the alternatives shall comply with these requirements for any actions that will disturb or otherwise manage or dispose of asbestos materials. 
DOE/RL-96-85

Rev. 0

\subsubsection{Worker Protection}

Worker protection standards are described in Occupational Safety and Health Administration regulations, national consensus standards, and DOE Orders; e.g., 29 CFR 1910, 29 CFR 1926, NFPA 70 (NFPA 1990), and WAC 296. The 29. CFR 1910 establishes exposure limits, personnel protection requirements, and decontamination methods for hazardous chemicals. Additionally, 29 CFR 1910 requires identification and mitigation of physical hazards posed by a facility to workers including but not limited to confined spaces, falling hazards, fire, and electrical shock. The 29 CFR 1910 provides requirements for worker safety during construction activities. DOE Orders require analysis of hazards posed by work activities and identification of controls necessary to work safely. The substantive requirements of these standards will be met for any S\&M, decommissioning, or demolition activities. Site and activity specific requirements and controls will be identified in final design and work plan documents, including contingency plans and emergency response plans.

\subsection{LONG-TERM EFFECTIVENESS}

The long-term effectiveness and permanence criterion assesses whether the alternative leaves an unacceptable risk after remedial activities have concluded. The no-action alternative would increase, rather than decrease, risk in the long term due to the increasing difficulty of maintaining the integrity of the facilities and confinement of hazardous substances. Ultimately, the facilities would require major upgrades beyond the scope of routine maintenance, or a decommissioning option would have to be implemented.

All demolition alternatives provide a high degree of long-term effectiveness by moving hazardous substances from a condition where they are potentially subject to release to a disposal condition where they are more easily contained. Although all of the demolition alternatives provide long-term effectiveness, the third alternative provides somewhat greater effectiveness by disposing of low-level radioactive waste at the ERDF rather than the LLBG.

\subsection{REDUCTION OF TOXICITY, MOBILITY, OR VOLUME}

This criterion, reducing toxicity, mobility, or volume through treatment, assesses whether the alternative permanently and significantly reduces the hazard posed. This could be accomplished by destroying the contaminants, reducing the quantity of contaminants, or irreversibly reducing the mobility of the contaminants.

The no-action alternative and continued S\&M provides no near-term reduction in toxicity, mobility, or volume through treatment. Toxicity would be reduced for radioactive contaminants as they decay over time, but for long-lived radionuclides (such as plutonium and nonradioactive contaminants), this would not be a practical means of reducing risk. 
All demolition alternatives would provide reduced mobility of contaminants by placing them in subsurface disposal locations, and reduced volume by using mechanical methods where possible to physically compact volumes of waste going to the ERDF, LLBG, or W-025 facility. Alternatives three and four would also provide reduced mobility and volume through decontamination, which would serve to remove contaminants from structural materials and consolidate them, therefore reducing the overall waste volumes; or fix contamination on surfaces, thus reducing mobility.

\subsection{SHORT-TERM EFFECTIVENESS}

This criterion assesses whether the alternative provide adequate protection of human health and the environment during the remedial action, and how long it will take for the action to achieve the established objectives. Because public access to the 100 Areas is restricted and workers will not enter any of the facilities identified in the EE/CA, the no-action alternative is effective (but somewhat less effective than the remaining alternatives) for short-term protection of human health and the environment. There is no time frame in which the no-action alternative will achieve the removal action objectives.

Public access to the 100 Areas is currently restricted, and current S\&M activities are generally sufficient to contain hazardous substances within the facilities; therefore, continued S\&M is effective in the short term to provide protection of the public and environment. The requirement for personnel to continue entering the facilities for $S \& M$ presents a risk to workers because of the aging condition of those facilities. There is no time frame in which continued S\&M will achieve the removal action objectives.

The third and fourth alternatives, which include decontamination, provide adequate protection of human health and the environment during implementation. The primary risk to the public and environment would be from the spread of contaminants during demolition. Measures, such as removing contaminants from surfaces or fixing contamination prior to demolition and spraying water for dust control, would be used to mitigate this risk. There will be a somewhat increased risk to workers versus the no-action alternative, primarily with the standard industrial risks associated with demolition. Appropriate precautions would be taken to protect workers from industrial hazards and hazardous substances that may be encountered.

\subsection{IMPLEMENTABILITY}

The implementability criterion assesses whether the alternatives are technically and administratively feasible. The no-action alternative is implementable. Continued S\&M consists of continuing current practices and could be easily implemented. The third and fourth alternatives could be implemented using standard decommissioning techniques. 


\section{$5.7 \quad$ COST}

The cost criterion evaluates whether the alternatives are cost effective. The cost for the no-action alternative is negligible because it consists of institutional access controls already in use at the Hanford Site. The annual cost of S\&M for the facilities evaluated in this report is approximately $\$ 200,000.00$ This cost, at a minimum, would be incurred annually as long as the facilities remain in their current condition. This does not include the cost of major maintenance upgrades (such as new roofs) that would be required as the facilities continue to deteriorate, nor does it include cost for future decommissioning currently identified in Tables 4 and 5. Both the 105-C Reactor and the 108-F Biology Laboratory would need new roofs if the no-action alternative is implemented, at a cost of several million dollars.

The costs for the third alternative, decontamination and demolition with disposal at ERDF, are shown in Table 4. The total cost for this alternative is approximately $\$ 23.7$ million. The costs for the third alternative, decontamination and demolition with disposal at other Hanford Site facilities, are shown in Table 5. The total cost for this alternative is $\$ 25$ million.

Table 6 compares the costs of the continued S\&M costs from 1997 through 2018 with the costs of the D\&D ERDF disposal alternative; and the D\&D, other Hanford facility disposal alternative.

\section{Table 6. Cost Comparison of Decontamination and Demolition and the Continued Surveillance and Maintenance Costs.}

\begin{tabular}{|c|c|}
\hline $\begin{array}{l}\text { S\&M (years } 1997 \text { to } 2018 \text { with } \\
\text { inflation) }\end{array}$ & $\$ 4,594,000.00$ \\
\hline $\begin{array}{l}\text { Roof repairs (foaming) } \\
\cdot 105-\mathrm{C} \\
\cdot 108-\mathrm{F} \\
\text { TOTAL S\&M }\end{array}$ & $\begin{array}{r}1,500,000.00 \\
300,000.00 \\
6,394,000.00\end{array}$ \\
\hline D\&D, ERDF disposal & $5,461,870.00$ \\
\hline D\&D, other Hanford Site disposal & $6,683,920.00$ \\
\hline \multicolumn{2}{|c|}{$\begin{array}{l}\text { Implementation of both decommissioning alternatives in the near term, compared to } \\
\text { continued S\&M, provides a } \$ 6,394,000.00 \text { cost savings over the lifecycle } \\
\text { management of the buildings identified in this EE/CA. }\end{array}$} \\
\hline $\begin{array}{l}\text { Disposal at ERDF, compared to exc } \\
\$ 1,222,050.00 \text { cost savings for dece }\end{array}$ & $\begin{array}{l}\text { es a } \\
\mathrm{d} \text { in this } \mathrm{EE} / \mathrm{CA}\end{array}$ \\
\hline
\end{tabular}

Because these facilities have not yet been characterized for pre-demolition planning, the costs are based on best available estimates using the U.S. Army Corps of Engineers MCACES construction estimating model. The costs assume the use of standard demolition techniques and practices as described in Section 3. 
DOE/RL-96-85

Rev. 0

\subsection{STATE ACCEPTANCE}

The state acceptance criterion evaluates whether the technical and administrative concerns of the state have been addressed. This criterion will be evaluated following public review.

\subsection{COMMUNITY ACCEPTANCE}

The community acceptance criterion evaluates how the alteratives address the concerns of the local community. This criterion will be evaluated following the public comment period.

\subsection{OTHER CONSIDERATIONS}

In accordance with DOE Order 451.1 and NEPA policy, DOE CERCLA documents are required to incorporate NEPA values such as analysis of cumulative, offsite, ecological, and socioeconomic impacts, to the extent practicable.

Cumulative impacts may occur because of interactions with other activities occurring in the 100 Area. Other activities in the 100 Area include the following:

- Remediation of waste sites and groundwater in the reactor areas

- $\quad$ Safe-storage activities for the 105-C Reactor

- Deactivation activities at the $100-\mathrm{N}$ Area

- Storage and removal of spent fuel contained in basins at the 100-K Area.

All of these activities contribute to the goal of cleanup of the 100 Areas and protection of the Columbia River. Implementation of the no-action alternative and continued S\&M would not be expected to contribute directly to cumulative impacts of these other activities; however, budget resources required to continue $S \& M$ would not be available to these other programs.

Furthermore, both the no-action and continuing S\&M alternatives would not support the overall Hanford Site priority of remediating areas along the Columbia River. The overall cumulative effects of the demolition alternatives and other 100 Area activities would be to enhance the protection of workers, the public, and the environment, which is consistent with the values expressed by the regulators, stakeholders, and public. Implementation of both demolition alternatives with prior decontamination would contribute less to overall airborne emissions from the 100 Area. Both demolition alternatives would ultimately reduce $S \& M$ costs, making more funding available to other cleanup programs, and would support the priority of cleanup along the Columbia River.

Offsite impacts include impacts to the public or the environment due to releases of contaminants resulting from an activity. The no-action alternative and continued S\&M would not be expected to result in offsite impacts in the near term. Continued confinement of hazardous substances in the facilities would become more difficult with time, and the potential for offsite impacts would 
increase. The third and fourth demolition alternatives would potentially result in airborne emissions of hazardous substances, but significant or long-term impacts are not expected.

None of the alternatives would be expected to affect existing natural resource conditions. Although bald eagles frequent the Columbia River during the winter, there are no identified roosts near the $100-\mathrm{B} / \mathrm{C}$ Area. The surveys indicate that the proposed activity is unlikely to disturb sensitive plant or animal species. Prior to initiation of any specific field activity, an ecological review of the facility and surrounding area will be conducted to ensure there will be no impacts to natural resources (e.g., migratory birds).

No unmitigated impacts to cultural resources are expected from any of the alternatives. Cultural resource reviews currently underway will identify whether any of the facilities addressed in this $\mathrm{EE} / \mathrm{CA}$ are potentially eligible for inclusion on the National Register of Historic Places. If that determination is made, appropriate actions will be taken to mitigate impacts.

Socioeconomic impacts from any of the alternatives would be minimal. The work force required for current S\&M activities is small. The personnel required to accomplish any of the demolition alternatives would be selected from the existing S\&M and remediation work force at the Hanford Site or available subcontractors. 
DOE/RL-96-85

Rev. 0 
DOE/RL-96-85

Rev. 0

\subsection{RECOMMENDED REMOVAL ACTION ALTERNATIVE}

Based on overall effectiveness, long- and short-term effectiveness, implementability, and cost, the recommended removal alternative for the five $100-\mathrm{B} / \mathrm{C}$ Area facilities and the 108-F Biology Laboratory is to decontaminate and demolish the structures and dispose of associated wastes. Waste will be disposed at ERDF with the option of disposing hazardous waste offsite and utilizing existing Hanford Site storage or disposal facilities for waste not meeting ERDF waste acceptance criteria. This alternative removes the potential for a release of hazardous substances that could adversely impact human health and the environment, is protective of workers, reduces $\mathrm{S} \& \mathrm{M}$ costs, and is consistent with other cleanup activities in the 100 Area. 
DOE/RL-96-85

Rev. 0 
DOE/RL-96-85

Rev. 0

\subsection{SCHEDULE}

Figure 5 provides schedules for information purposes only. The schedules are subject to changing budget constraints. Sampling and analysis plans (for waste designation and final verification) and the final report for each building identified will be submitted to EPA for concurrence.

The assessment phase (identified in Figure 5) includes cultural resource and biological reviews, preparation of site-specific health and safety procedures, and analysis of existing data for use in later activities. The project plan is essentially the design of work activities in the field and is equivalent to a removal action design report. 


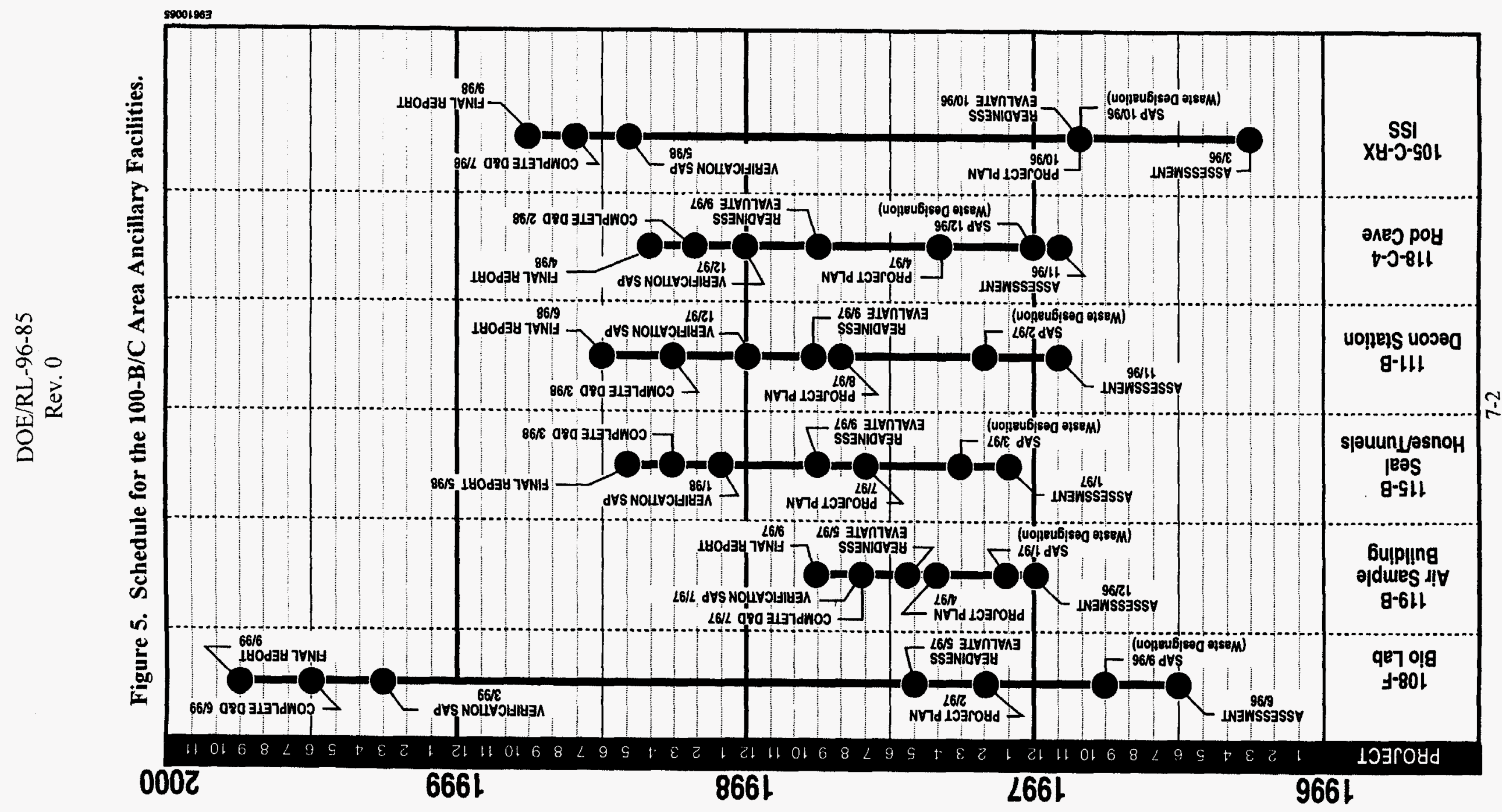


DOE/RL-96-85

Rev. 0

\subsection{REFERENCES}

Archaeological and Historic Preservation Act of 1974, 16 U.S.C. 469, et seq.

AEC-GE Study Group for the Economic Development of Richland, 1964, Catalog of Hanford Buildings and Facilities, 100 Areas, General Electric Corp., Richland, Washington.

BHI, 1996, Removal Evaluation for the 100-B/C Area Ancillary Facilities and the 108-F Building, BHI-00728, Bechtel Hanford, Inc., Richland, Washington.

Clean Air Act, 42 U.S.C. 7401, et seq.

Clean Water Act, 33 U.S.C 1251, et seq.

Comprehensive Environmental Response, Compensation, and Liability Act of 1980, 42 U.S.C. 9601 , et seq.

Cushing, C.E., 1995, Hanford Site National Environmental Policy Act (NEPA) Characterization, PNL-6415, Rev. 7, Pacific Northwest National Laboratory, Richland, Washington.

Delphinus Engineering, 1995, Engineering and Planning for Reactor 105-C Long Term Storage Conceptual Design Report, Vol. 1, Delphinus Engineering, Inc., Philadelphia, and Raytheon Engineers and Constructors, Richland, Washington.

DOE, 1993, Decommissioning of Eight Surplus Production Reactors at the Hanford Site, Richland, Washington, DOE/EIS-0119, Rev. 0, Richland, Washington.

DOE, 1996a, Remedial Design Report/Remedial Action Work Plan for 100 Area, DOE/RL-96-17, Rev. 0, Richland Washington.

DOE, 1996b, Sampling and Analysis Plan for the 100-BC-1, 100-DR-1, and 100-HR-3 Operable Units, DOE/RL-96-22, Rev. 0, Richland Washington.

Dorian, J. J., and V. R. Richards, 1978, Radiological Characterization of the Retired 100 Areas, UNI-946, UNC Nuclear Industries, Richland, Washington.

Douglas United Nuclear, 1971, Radiological Status Report - Radiological Status Report Deactivation of the 105-C Reactor Plant, DUN-7623, Richland, Washington.

Ecology, EPA, and DOE, 1990, Hanford Federal Facility Agreement and Consent Order, 2 vols., as amended, Washington State Department of Ecology, U.S. Environmental Protection Agency, and U.S. Department of Energy, Olympia, Washington. 
EPA, 1995a, Record of Decision for the Environmental Restoration Disposal Facility, Environmental Protection Agency, Richland, Washington.

EPA, 1995b, Record of Decision, USDOE Hanford 100 Area, 100-BC-1, 100-DR-1, and 100-HR-1 Operable Units, Environmental Protection Agency, Richland, Washington.

Ecology, EPA, and DOE, 1990, Hanford Federal Facility Agreement and Consent Order, 2 vols., as amended, Washington State Department of Ecology, U.S. Environmental Protection Agency, and U.S. Department of Energy, Olympia, Washington.

Endangered Species Act of 1973, 16 U.S.C 1531, et seq.

Gerber, M. S., 1993a, Summary of 100-B/C Reactor Operations and Resultant Wastes, Hanford Site, WHC-SD-EN-RPT-004, Rev. 0, Westinghouse Hanford Company, Richland, Washington.

Gerber, M. S., 1993b, Manhattan Project Buildings and Facilities at the Hanford Site: A Construction History, WHC-MR-0425, Westinghouse Hanford Company, Richland, Washington.

Griffin, P. W., 1989, Facility Decommissioning Report for the 115-B/C Gas Recirculation Facility, WHC-SD-DD-TI-042, Westinghouse Hanford Company, Richland, Washington.

Hazardous Materials Transportation Act, 49 U.S.C 1801-1813, et seq.

Kiser, S., 1984, 100 Deactivated Area Pictorial Review, UNI-2780, UNC Nuclear Industries, Inc., Richland, Washington.

Kiser, S. L. and T. L. Witt, 1994, 100 Deactivated Area Pictoral Review, UNI-2780, UNC Nuclear Industries Inc., Richland, Washington.

Migratory Bird Treat Act, 16 U.S. C. 703, et seq.

National Archeological and Historical Preservation Act, 16 U.S.C 469, et seq.

National Environmental Policy Act of 1969, 42 U.S.C. 4321, et seq.

National Historic Preservation Act of 1966, 16 U.S.C. 470, et seq.

NFPA, 1990, National Electrical Code, NFPA 70, National Fire Protection Association, Quincy, Massachusetts.

Resource Conservation and Recovery Act of 1976, 42 U.S.C. 6901, et seq. 
Rev. 0

Roeck, F.V., 1996, Environmental Restoration Disposal Facility Waste Acceptance Criteria, BHI-00139, Rev. 3, Bechtel Hanford, Inc., Richland, Washington.

Safe Drinking Water Act, 40 U.S.C.300, et seq.

Toxic Substance Control Act of 1976, 15 U.S.C, et seq.

Wahlen, R. K., 1991, Summary of the Hanford Site Decontamination, Decommissioning and Cleanup FY1974 Through FY1990, WHC-EP-0478, Westinghouse Hanford Company, Richland, Washington. 
DOE/RL-96-85

Rev. 0 
Number of Copies

\section{ONSITE}

U.S. Department of Energy

Richland Operations Office

21

J.M. Bruggeman (20)

$\mathrm{H} 0-12$

DOE/RL Public Reading Room

H2-53

36

ERC Team

E.T. Coenenburg

H9-11

J.H. Dunkirk

$\mathrm{H} 0-13$

J.R. Eidam

$\mathrm{X} 3-40$

R.P. Henckel

$\mathrm{X} 5-53$

P.K. Jackson

$\mathrm{X} 5-53$

R. J. Landon

$\mathrm{H} 0-18$

N.C. Little

$\mathrm{X} 5-53$

J.J. McGuire

$\mathrm{X} 5-53$

L.A. Mihalik

H9-01

M.A. Mihalic

$\mathrm{X} 5-53$

L.R. Miller

$\mathrm{X} 5-53$

R.L. Miller

$\mathrm{X} 5-53$

J.E. Rugg (5)

$\mathrm{X} 5-53$

J.P. Zoric

$\mathrm{X} 5-57$

AR File (9)

H0-09

D\&D Project File (3)

H0-09

BHI Document Information Services (3)

H0-09

PNNL Hanford Technical Library (2)

P8-55 